\title{
ANALISIS STRATEG I PENGEMBANGAN REKAM MEDIS ELEKTRONIK DI INSTALASI RAWAT JALAN RSUD KOTA YOGYAKARTA
}

\author{
M uhammad Hamdani Pratama', Sri Darnoto² \\ 1,2Program Studi Kesehatan Masyarakat, Fakultas IImu K esehatan, Universitas M uhammadiyah \\ Surakarta danimuhammadtama@gmail.com
}

\begin{abstract}
Although developing countries are still concernin handling various infectious diseases but effective and efficienthealth care documentation process is needed (Kalogriopoulos et all. 2009). The implementation of electronic medical record (EMR) is a solution for effective and efficient documentation. Support of the electronic and transaction laws and Ministri of Health Regulation No.269 in year of2008 bright hope for the development of EMR. Provision of medical record file is still a problem in Yogyakarta General Hospital. In addition, medical records storage space is over capacity. Optimizing of medical records service provision need to be reviewed to minimize the use of paper and time efficiency. The purpose of this study was to analyze the development strategies outlined by EMR readiness analysis used instruments of DOQ-IT (Doctor's Office Quality-Information Technology) and strategy analysis used SWOT (Strengths, Weakness, Opportunities, Treats) instrument. Thisstudy used concurrent mix methode. Subjects in this study were 40 peoplewho are the decision makers and users of EMR in Outpatient Install lation of Yogyakarta General Hospital. The coll lection of data through interviews and questionnaires. The results showed that the Yogyakarta General Hospital in the moderately prepared category for EMR development. The results of the strategy analysis showed that Yogyakarta General Hospitals included in II quadrant, which showed a strong organization but faces many threats to develop EMR. The recomendation for thestrategies is diversification strategy.
\end{abstract}

Keyword: Readiness Analysis, DOQ-IT, Strategic Analysis, SWOT

\begin{abstract}
Abstrak
Negara berkembang masih disibukkan dengan penanganan berbagai penyakit infeksi atau penyakit menular namun proses dokumentasi pelayanan kesehatan yang efektif dan efisien sangat dibutuhkan (Kalogriopoulos et all, 2009). Penerapan rekam medis elektronik (RME) menjadi sal ah satu solusi dokumentasi yang efektif dan efisien. Dukungan adanya UU ITE Tahun 2008 dan Permenkes 269 Tahun 2008 mengenai keabsahan RME sebagai bukti hukummemberikan harapan cerah bagi perkembangan RME. Permasal ahan penyediaan berkas rekam medis masi h menjadi permasal ahan di RSUD Kota Yogyakarta.Selain itu, nuang penyimpanan rekam medis juga sudah melebihi kapasitas.Optimal isasi pelayanan penyedian berkas perlu ditinjau ulang untuk meminimalkan penggunaan kertas dan efisiensi waktu.Untuk itu pengembangan RME sangat di butuhkan. Tujuan dari penelitian ini adalah untuk melakukan analisis strategi pengembangan RME yang dijabarkan dengan anal isis kesiapan pengembangan RME menggunakan instrumen dari DOQ-IT (Doctor 's Office QualityInformation Technology) dan anal isis strategi SWOT (Strengths, Weakness, Opportunities, Treats). Penelitian ini menggunakan concurrent mixed methodedengan rancangan studi kasus. Subjek dalampenelitian ini adal ah 40 orangyang merupakan pi hak pengambil keputusan dan pengguna RME di Instal asi RawatJ alan RSUD Kota Yogyakarta. Pengumpulan data melal ui wawancara mendalam dan kuesioner. Hasil penel itian menunjukkan bahwa RSUD Kota Yogyakarta masuk dalam kategori cukup siap untuk pengembangan RME. Hasil analisis strategi menunjukkan RSUD Kota Yogyakarta masuk dalam kuadran II yang menunj ukkan organisasi yang kuat namun menghadapi banyak ancaman sehingga rekomendasi strategi yang diberikan adalah diversifikasi strategi.
\end{abstract}

Kata kunci: Analisis kesiapan, DOQ-IT, analisis strategi, SWOT 


\section{PENDAHULUAN}

Perkembangan rekammedis elektronik (RME) tidak hanya terjadi di negara-negara maju. Negaranegara berkembang mulai mengadopsi sistem elektronik untuk mendapatkan ekfektifitas dan efisiensi dalam pel ayanan kesehatan. Meskipun negara berkembang masih disibukkan dengan penanganan berbagai penyakit infeksi maupun penyakit menular namun proses dokumentasi pelayanan kesehatanyang efektif dan efisien sangat dibutuhkan (Kalogriopoulos etall, 2009). Di Indonesia, pengembangan RME belum diatur secara khusus. Namun, dukungan adanyaUU ITE Tahun 2008 dan Permenkes 269 Tahun 2008 mengenai keabsahan RME sebagai bukti hukum memberikan harapan cerah bagi perkembangan RME di Indonesia. RSUD KotaYogyakarta sebagai rumah sakit milik pemerintah telah memiliki Sistem Informasi Manajemen Rumah Sakit (SIMRS).

SIMRS RSUD Kota Yogyakarta sudah memiliki aplikasi terkait pengembangan rekam medis elektronik tetapi belum dimanfaatkan secara maksimal. Permasal ahan yang terjadi adal ah belum adanya rencana srategi terkait pengembangannya Tanpa adanya perencanaan yang jelas, proses pengembangan sistem informasi di RSUD Kota Yogyakarta terkesan tambal sulam Pengembangan rekam medis elektronik diperlukan adanya anal isis terkait kesiapan organisasi rumah sakit terlebih dahulu. Jogiyanto (2005) menyebutkan bahwa kecanggihan teknologi informasi tidak akan menghasilkan keuntungan kompetitif berkelanjutan jikatidak direncanakan dengan baik. Proses anal isis kesiapan dapat dilanjutkan dengan melakukan anal isis strategi pengembangan rekam medis elektronik sebagai bentuk perencanaan dalam usaha mencapai tujuan yang kompetitif. Melihat permasalahan yang ada di RSUD Kota Yogyakarta terkait pengembangan rekammedis elektronik, maka peneliti tertarik untuk melakukan penelitian dengan judul Analisis Strategi Pengembangan RekamM edis Elektronik di Instalasi Rawat Jalan RSUD Kota Yogyakarta.

Tujuan yang ingin dicapai dalam penelitian ini adalah:

MelakukanAnal isiskesiapan pengembangan rekam medis elektronik di Instal asi Rawatj alan RSUD Kota Yogyakarta berdasarkan instrumen dari DOQ-IT EHRAssessment and Readiness;

Melakukan Analisisstrategi pengembangan rekam medis di Instalasi Rawat Jalan RSUD Kota
Yogyakarta dengan metode SWOT (Strength, Weakness, Opportunities, Treaths).

\section{METODE}

Penelitian ini menggunakan concurent mix method dengan rancangan penelitian studi kasus.Analisis kual itatif di lakukan untuk mendapatkan hasil anal isis yang mendalam dan menyeluruh dengan didukung dari hasil studi kasus di lokasi penelitian. Data kuantitatif digunakan untuk melakukan pengukuran kesiapan dan mengetahui variabel strategi yang paling kuat dalam strategi pengembangan RME di RSUD KotaYogyakarta. Penelitian ini dilaksanakan di RSUD Kota Yogyakarta pada bulan A pril dan Mei 2016. Objek penelitian adalah pengembangan RME sedangkan subjek penelitian ini adalah 40 orang yang terdiri dari: direktur, kepala Instalasi TI, kepala instalasi rekam medis, kepala instalasi rawatjal an, kepala bi dang pelayanan, kepalabidang keperawatan, kepalaseksi rawatjalan, wakil direktur pelayanan, teknisi $\mathrm{TI}$, petugas rekam medis rawat jalan, 17 perawat, 12 dokter.

\section{HASIL DAN PEMBAHASAN}

A nalisis Kesiapan Pengembangan Rekam M edis E lektronik (R M E) di I nstalasi R awat J alan R SUD K ota Yogyakarta B erdasarkan Instrumen DOQIT EHRAssessmentand Readiness

Pengembangan RME memelukan proses analisis kesiapan. Proses analisis terhadap kesiapan penerapan RME dapat dilakukan untuk dapat menentukan "road map" dan memberikan gambaran apakah akan berlanjut pada el ectronic heal th record (California Medical Association, 2015). Proses analisis kesiapan sebelum di lakukan implementasi RME dapat dilihat dari beberapa aspek antara lai n: kesiapan organisasi, kesiapan struktur, kesiapan budaya, kesiapan manajemen dan kepemimpinan, kesiapan operasional, kesiapan pemerintah, kesiapan teknis (Ghazisad di et all, 2013). Untuk menentukan road map dan keberlanjutan program pengembangan rekam medis elektronik di RSUD Kota Yogyakarta juga di butuhkan anal isis kesiapan kondisi sumberdaya manusia, budaya, tata kelola kepemimpnan serta infrastruktur (DOQ-IT, 2009).

\section{Sumberdaya M anusia}

Hasil penelitian menunjukkan bahwa sebagai besar SDM di RSUD KotaYogyakartamemahami arti dari 
RME.Pengembangan RME akan sangat tergantung padasumberdayamanusia(SDM) sebagai pengguna RME maupun sebagai penyusun kebijakan. RME merupakan sistem otomatis yang terdiri dari indentifikasi pasien, pengobatan, peresepan, hasil labol atorium dan di dokumentasikan ol eh dokter saat pasien berkunjung (WHO, 2006).

RSUD Kota Yogyakarta memiliki staf TI sebanyak 6 orang untuk mendukung berjalannya kegiatan teknologi informasi termasuk dalam pemeliharaan SIMRS. Dal am proses pengambilan keputusan staf ikut serta memberikan masukan-masukan terkait proses SIMRS. Peraturan Menteri Kesehatan Republik Indonesia Nomor 82 tahun 2013 tentang Sisteml nformasi Manajen RumahSakitmenyebutkan bahwa Sumber daya manusia teknologi informasi untuk SIMRS minimal terdiri dari staf yang memiliki kualifikasi dalam bidang analisis sistem, programmer, hardware dan maintanance jaringan (Kemenkes, 2013). Dalam hal kualifikasi untuk analisis sistem belum terli hat adanya staf TI yang memanfaatkan kualifikasi tersebut.Jumlah staf dengan kemmapuan program berjumlah 2 orang, namun demikian pada pelaksanaannya masih mengal ami hambatan terkait keterbatasan pengembangan program dan pemberian reward untuk untuk setiap program yang dikembangkan.

Salah satu isu penting yang memerlukan perencanaan matang adalah terkait dengan ketersediaan sumber daya manusiabesertakemmapuannya (WHO, 2006). Untuk itu perencanaan SDM hanus terdokumentasi dan diusul kan pada pi hak kepegawaian.Kemampuan staf dalam mengoperasikan komputer juga menjadi komponen penting dalammendukung pengembangan RME.

Sebagian besar dari responden bisa menggunakan komputer dengan minimumbantuan sebesar 43,59\%. Hasil penelitian Kool aeeet all, (2014) menunjukkan bahwa rerata kesiapan staf dalampenerapan EHR adalah sebesar 56\%. Disarankan adanya pelatihan dan pengenal an terlebih dahul u dal amimplementasi EHR. Keikutsertaan staf dalam proses rencana, pelaksanaan dan implementasi EHR juga efektif dalam mempromosikan sikap positif. Berdasarkan Penilai an dari DOQ-IT (2009), maka elemen yang harus di penuhi adalah terkait analisis produk dari vendor, serta mampu mengeval uasi al ur kerja RME nantinya. Dibutuhkan identifikasi kemampuan staf TI sesuai keahlian dan secara mandiri dapat mengembangkan sistem yang sudah ada.

\section{Budaya K erja Organisasi}

Budaya memiliki peran penting karena merupakan acuan prilaku, dari aspek ini jugaterlihat bagaimana tanggapan pengguna RME nantinya dalammenerima pengembangan sistem RME. Pada Aspek Budaya kerja organisasi terdapat 11 komponen yang dinilai dengan 4 area kesiapan yaitu budaya, keterlibatan pasien, Alur kerja proses dan Manajemen I nformasi. RME di RSUD Kota Yogyakarta telah dipandang sebagai sebuah bentuk alur kerja yang efisien. Kaitanya dengan tujuan perencanaan, peni laianjuga dilakukan pada komponen kualitas dan efisiensi. Responden dari jajaran manajemen mengungkapkan bahwa salah satu tujuan RME adalah untuk efisiensi. Efisiensi tersebut diikuti dengan kualitas dari sistem yang mendukung. Setelah dilakukan penelitian dari beberapa rumah sakit dari tahun 2007 hingga tahun 2009 terlihat bahwa EHR memberikan peningkatan kualitas pelayanan, patient safety dan efisiensi (Carroll et all, 2012).

Staf medis dan administrasi maupun pihak jajaran manajemen juga menganggap RME dapat memberikan peningkatan kual itas pel ayanan namun harus didukung dengan sistem kerja yang jelas dan SDM IT yang handal. EHR dapatmendukung adanya keselamatan pasien serta peningkatan kual itas pelayanan.EHR didukung dengan adanya chceklist, pemberian warning, klinical guidlines yang sesuai standar. (Carroll et all, 2012).

Keberhasilan pengembangan RME tersebut tidak hanya terlepas dari sistem yang sudah dibuat. Sistemyang disusun harus sesuai dengan kebutuhan pengguna. Carroll et all (2012) dal ampenelitiannya menyebutkan bahwa salah satu kesuksesan dalam implementasi RME adalah dengan adanya keikutsertaan staf klinis maupun administrasi dalam proses desai n dan perencanaan implementasi. Untuk menuju pada perubahan tersebut, dokter maupun staf medis perawat menyadari bahwa sebagai pengguna memiliki peran yang penting dalam memberikan masukan. Namun demikian untuk proses inventarisasi kebutuhan belum terdapat tim khususyang dapat mewadahi perencanaan tersebut. RSUD KotaYogyakarta bel ummemiliki timkhusus yang disusun dalam perencanaan sistem informasi dan teknologi informasi. Dan pada akhimya proses masukan hanya sebatas pemberian masukan tanpa adanya proses dokumentasi. Proses perbaikan atau permintaan modul tertentu untuk menyempurnakan SIMRS di lakukan setelah di lapangan membutuhkan. 
Selain keterlibatan pengguna maupun jajaran manajemen, pengembangan RME jugamemerlukan keterlibatan pasien.Keterlibatan pasien dilihat dengan melakukan evaluasi terhadap pelayanan yang diberikan kepada pasien. Menunut pandangan responden, interaksi pasien dengan RME menjadi pertimbangan sebatas sebagai bahan evaluasi.

Penilaian kesiapan juga dilakukan pada alur kerja proses RME. Alur kerja proses ini menyangkut proses administrasi klinistermasuk perkiraan pasien dan staf yang di butuhkan. Namun demikian perkiraan kebutuhan staf tersebut belum dikembangkan khususnyauntuk penerapan RME. Selain parameter tersebut juga dinilai terkait kebijakan, prosedur dan protokol yang di perlukan untuk proses menuju RME. Penilaianterhadap parameter tersebut di lakukan pada SIMRS yang ada saat ini.Prosedur-prosedur terkait SIMRS yang telah di atur adalah pada koreksi data pasien. Prosedur lain terkait perencanaan ke arah RME belum dilaksanakan.

Manajemeninformasi merupakanareapenilaianyang terkait dengan praktik pengel ol aan sisteminformasi. Salah satu tantangan dari implementasi EHR adalah penggunaan EHR untuk melihatperformancerumah sakit.Tantangan utamanya adal ah adanya data yang tidak sesuai dengan kondisi lapangan. Dalam hal ini proses entry data sesuai standar menjadi tombak utama untuk kesuksesan penggunaan EHR untuk pelaporan (WHO, 2006). Dan kondisi ini apabila dilihat dari sisitem yang sudah ada di RSUD Kota Yogyakarta yaitu SIMRS yang berjal an, maka dapat dikatakan bahawa fungsi manajemen informasi bel umberfungsi optimal.Berdasarkan penilaian dari DOQ-IT (2009) maka banyak aspek yang belum terpenuhi pada area budaya kerja ini.Beberapa diantaranya adalah terkait keaktifan tenaga medis dal am ikut serta untuk perencanaan sistem Perlu adanya identifikasi steakholder yang terlibat dari EMR serta mengi kutsertakan dal am tim perubahan (Katterhagen, 2013). Selain itu ketakutan beberapa petugas terkait pemanfaatan teknologi terhadap pelayanan yang diberikan kepada pasien harus diatasi dengan memberikan motivasi dan sosialisasi mengenai penggunaan teknologi infromasi.

\section{Tata Kelola Kepemimpinan}

Kesuksesan dalam proses implementasi EMR dipengaruhi oleh dukungan kepemimpinan yang kuat, keikutsertaan dari staf klinis dalam desain dan impelmentasi, proses pelatihan pada staf, serta proses perencanaan yang sesuai jadwal serta penyediaan anggaran yang memadai (Carroll et all, 2012). Peran dukungan kepemimpinan dan tata kel olanya berpengaruh pada pengembangan RME karenapemimpinmenupakanjajaran tertinggi dalam pengambilan keputusan.Penilaian areadankomponen tata kelola kepemimpinan terdiri dari dukungan pemimpin, strategi, dukungan manajemen TI serta akuntabilitas dari SIMRS. Area Kepemimpinan terdiri dari duakomponen yaitu dukungan pemimpin terhadap pengembangan RME dan penilaian adanya tim eksekutif untuk pengembangan RME. Saat ini timeksekutif terkaitpengembangan sisteminformasi dan teknologi informasi di RSUD Kota Yogyakarta. Hal ini berdampak pada proses perencanaan yang didasarkan pada masukan dan komplain dari pengguna di lapangan.

Critical element pertama untuk keberhasilan implementasi RME adalah terkait team leadership. EMR Leadership team merupakan komite yang mengkomando proses proses dal am pengembangan. Di dalam team tersebut terdiri dari berbagai pi hak interdisipliner yang bersedia meluangkan waktu untuk ikut serta dalam proses pengembangan sistem (Healtland, 2009). Tim khusus tersebut saat ini belum ada di RSUD Kota Yogyakarta sehingga untuk proses pengembangan ke depan diperlukan pembentukan timeksekutif dal amperencanaasistem informasi rumah sakit. Timeksekutif tersebut harus benar-benar terlibat dalamsemua tahap implementasi dengan menyediakan pendapat dari berbagai pengguna, inovasi, waktu dan komitmen.Selain itu juga dibutuhkan manajer yang kuat dan pemimpin senior manajer klinis dan tenaga klinis (Ghazisael di et al, 2013).

National Learning Consortium(2013) menyebutkan bahwatimeksekutif sistemEHR terdiri dari berbagai profesi. Profesi tersebut antara lain pemimpin Tim EHR, Manager Implementasi EHR, Tim Dokter, pimpinan perawat, Medical AssistantLead, Pimpinan pengatur jadwal, Pemimpinstaf registrasi, Pemimpin staf Iabolatorium, Pemimpin Teknologi Informasi, Pemimpin Staff Biling, EHR Builder, Meaningful Use Lead, Workflow Redesign Lead, Super-User/ Training Lead.Profesi-profesi tersebut ikut serta dalam pengambilan keputusan perencanaan sesuai dengan tugasnya masing-masing.Area kesiapan tata kelola kepemimpinan yang perlu mendapatkan perhatian segera adal ah terkait strategi.RSUD Kota Yogyakarta belummemiliki rencana strategi khusus mengenai sisteminformasi danteknologi infromasi. 
Selain itu pengembangan RME juga belumtercantum dalam proses perencanaan.

\section{Infrastruktur}

Adopsi EHR secara menyel uruh memerlukan biaya yang banyzk dan memerlukan proses yang Panjang (Carroll et all, 2012). Untuk itu diperlukan adanya kesiapan dari sisi infrastruktur TI maupun anggarannya.Area penilaian I nfrastruktur terdiri dari Infrastruktur TI serta Keuangan dan A nggaran. Salah satu kendala dalam pengembangan RME adalah kaitannya dengan anggaran untuk teknologi informasi di rumah sakit cenderung terbatas.Aspek finansial menjadi perseolan penting karena rumah sakit harus menyiapkan infrastruktur teknologi informasi (komputer, jaringan kabel maupun nir kabe, listrik, sistem pengamanan, konsultan, dan pelatihan) (Handi widjojo, 2009).Namun demikian penyediaananggaran kaitannya dengan TI cenderung lebi h mudah didapatkan di RSUD Kota Yogyakarta. Hal ini dikarenakan komitmen jajaran manajemen yang telah tertuang dalam misi rumah sakit untuk dapat mengembangkan pemanfaatan teknologi informasi.Meskipun padakenyataannya perencanaan khusus untuk pengembangan RME belum tertuang dengan jelas.

Pada area keuangan dan anggaran terdapat dua komponen penting yaitu terkait investasi RME serta anggaran terkait pemeliharaan yang berkesinambungan. A pabila rumah sakit telah memahami pentingnya RME maka RME akan dianggap sebagai sebuah investasi. Proses perencanaan untuk RME telah dipahami oleh banyak pi hak baik dari jajaran manajemen ataupun pengelola TI. Namun demikian proses evaluasi terhadap investasi RME belum dilakukan. Hasil penelitian Rizanti (2015) menunjukkan bahwa rumah sakit haji berada pada skala usaha yang meningkat increasing return to scale.Hal ini menunjukkan bahwa dengan adanya rekam medis elektronik maka terjadi peningkatan investasi rumah sakit. Melihathal tersebutmaka kedepannyadalamproses perencanaan pengembangan RME di RSUD Kota Yogyakarta perlu dibentuk pula salah satu bagian dalam tim eksekutif yang melakukan evaluasi terhadap pelaksanaan RME termasuk pada sisi investasi RME. Penilaian pada aspek infrastruktur berdasarkan DOQ-IT (2009) memeperlihatkan bahwa infrastruktur yang ada di RSUD Kota Yogyakarta masuk dalamkategori cukup. Meskipun masi h dalam kategori cukup, dukungan anggaran yang kuat dari jajaran manajemen memberikan dampak positif bagi pengembangan RME ke depan.

\section{Penilaian K esiapan Pengembangan RME}

Empat area kesiapan yaitu sumberdaya manusia, budaya kerja organi sasi, Tata kelola kepemimpi nan dan infrastruktur dinilai secara bersama-sama. Berikut hasil penilaiannya:

Tabel 3. Penilaian K esiapan Pengembangan R ME di R SUD Kota Yogyakarta

\begin{tabular}{|c|c|c|c|}
\hline No & $\begin{array}{l}\text { Area K esiapan } \\
\text { dan K omponen }\end{array}$ & Hasil Penilaian & $\begin{array}{c}\text { Skor } \\
\text { Sub } \\
\text { Total }\end{array}$ \\
\hline 1. & $\begin{array}{l}\text { Sumberdaya } \\
\text { Manusia }\end{array}$ & $\begin{array}{l}\text { Staf kl i ni k maupun } \\
\text { administrasi ikut berperan } \\
\text { dal a m memb er i kan } \\
\text { masukan untuk pengelolaan } \\
\text { SI M RS meski pun ti dak } \\
\text { didata secara menyel uruh. } \\
\text { Sudah dipahami mengenai } \\
\text { penti ngnya perencanaan } \\
\text { sumberdaya manusia terkait } \\
\text { pengembangan RME tetapi } \\
\text { bel um terdokumentasi kan } \\
\text { dal am rencana terperinci. } \\
\text { Sebagian besar responden bisa } \\
\text { mengoperasikan komputer. } \\
\text { Training terkaitSIMRS pernah } \\
\text { di lakukan namun dalam } \\
\text { kurun waktu yang sudah } \\
\text { lama. Pelatihan khusus terkait } \\
\text { bagaimanapengembangandan } \\
\text { adobsi RKE belum dilakukan } \\
\text { untuk staf dan manajer TI }\end{array}$ & 13 \\
\hline 2. & $\begin{array}{l}\text { Budaya Kerja } \\
\text { Organisasi }\end{array}$ & $\begin{array}{l}\text { Jajaran manajemen masi } \\
\text { memandang sebagai wacana } \\
\text { sehingga ti dak terli hat } \\
\text { framework yang nyata untuk } \\
\text { perencanaan RME. Dokter } \\
\text { memi li ki peran dal am } \\
\text { memberi kan keputusan } \\
\text { penting. Kebijakan terkait } \\
\text { koreksi pasien sudah dibahas } \\
\text { untuk penerapan padaSIMRS } \\
\text { namun bel um untuk RME. } \\
\text { Proses peresepan elektronik } \\
\text { sudah dirancang dan akan } \\
\text { segera diimplementasikan. } \\
\text { Alur kerja RM E bel um } \\
\text { terencana.RME dipandang } \\
\text { sebagai teknologi yang dapat } \\
\text { digunakan untuk efisiensi } \\
\text { pekerjaan. }\end{array}$ & 19 \\
\hline 3. & $\begin{array}{l}\text { Tata Kelola dan } \\
\text { Keperimpinan }\end{array}$ & $\begin{array}{l}\text { J aj aran manaj emen } \\
\text { mendukung adanya RME } \\
\text { namun demikian perencanaan } \\
\text { strategis terperinci mengenai } \\
\text { pengembanngan rekam medis } \\
\text { elektronik belum ada. }\end{array}$ & 14 \\
\hline
\end{tabular}




\begin{tabular}{|c|l|l|c|}
\hline No & $\begin{array}{c}\text { A rea K esiapan } \\
\text { dan K omponen }\end{array}$ & \multicolumn{1}{|c|}{ Hasil Penilaian } & $\begin{array}{c}\text { Skor } \\
\text { Sub } \\
\text { Total }\end{array}$ \\
\hline 4. & Infrastruktur & $\begin{array}{l}\text { A danya teknol ogi RME R } \\
\text { dipandang sebagai sebuah } \\
\text { investasi namun proses } \\
\text { Nerer kar ladr I ar lyyd arl secar a } \\
\text { khusus belum diidentifikasi } \\
\text { secara terperinci untuk proses } \\
\text { pengembangan RME }\end{array}$ & 5 \\
\hline & Total & 51 \\
\hline
\end{tabular}

Area kesiapan sumberdaya manusia berada pada range III yaitu dalam kategori cukup siap (DOQIT, 2009). Range III menunjukkan bahwa sudah terdapat pemahaman tentang RME dan bagaimana manfaatnya bagi rumah sakit. Sebagian besar sumberdaya manusia dapat mengoperasikan komputer namun masi h di perlukan adanya pel atihan untuk memperkecil kesenjangan antar stat medis. Area kesiapan budaya kerja organisasi memiliki skor sebesar 19 dari total skor untuk area ini sebesar 55, sehingga RSUD Kota Yogyakarta berada pada kategori range II yang mengindikasikan bahwa budaya kerja cukup siap (DOQ-IT, 2009). Range II mengindeikasikan bahwa telah ada pemahaman tentang perubahan budaya kerja organisasi yang mungkinterjadi bilaRME diterapkan. Masihterdapat perbedaan pendapat dan pemahaman mengenai perubahan sehingga diperlukan perencanaan untuk mengantisi pasi perbedaan pendapat dan pemahaman sebagai dampak yang mungkin terjadi terkait perubahan budaya kerja organisasi .

A rea kesiapan tata kelola dan kepemimpinan berada pada range II yaitu cukup siap.Range II Mengindikasikan telah ada pemahaman tentang nilai RME dari jajaran manajemen, tetapi belum seluruhnya.Ada beberapa kelemahan yang bisa digali lebih dalam dan rinci terkait strategi dan dukungan dari manajemen TI.Sedangkan untuk area kesiapan intrastruktur masuk dalam range II yang mengindikasikan bahwa infrastruktur cukup siap (DOQ-IT, 2009).I Infrastruktur sudah di pandang sebagai sebuah investasi, proses untuk penyediaan juga didukung pinak manajemen. Kelemahannya adalah proses penganggaran yang spesifik untuk pengembangan RME belum ada. Berikut ini grafik area kesiapan pengembangan RME di RSUD Kota Yogyakarta:

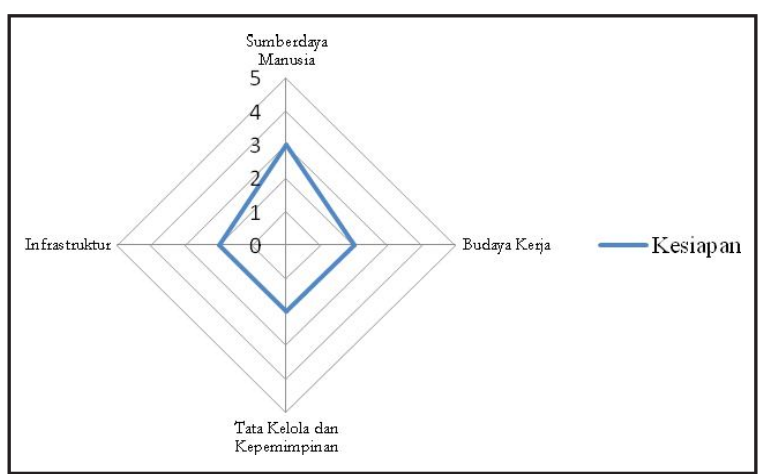

Gambar 2. Grafik A rea Kesiapan Empat K omponen dalam Pengembangan R M E di R SUD K ota Yogyakarta

A rea kesiapan pal ing tinggi berada pada sumber daya manusia. Meskipun masih dalam kategori cukup, namun sumber daya pendukung RME di RSUD Kota Yogyakarta sebagian besar mampu mengoperasikan komputer. Staf klinis khusunya perawat terbiasa melakukan proses entry data diagnosis dan billing melal ui SIMRS. Beberapa dokter jugatelah familiar dal am penggunaan RME.

Terdapat tiga area kesiapan yang masuk dalam kategori cukup siap yaitu infrastruktur, budaya kerja dan tata kel ol a kepemimpinan. I ntrastruktur di RSUD Kota Yogyakarta dinilai cukup untuk dapat mel akukan pengembangan RME. Pada area budaya kerja diperlukan adanya pemahaman mengenai perencanaan RME yang harus meli batkan berbagai steakhol der yang berhubungan dengan RME. Selain itu regulasi mengenai RME perlu diatur dalam kebijakan.Pada area tata kelola dan kepemimpi nan juga masi h di butuhkan adanya pembuatan rencana strategi pengembangan sistem infromasi dan teknol ogi informasi sebagai bentuk nyata keseriusan jaj aran manajemen dal am pengembangan rekam medis el ektronik. Penelitian Rahayu (2015) menunjukkan bahwa kesiapan di RSUD Dr. $\mathrm{H}$. Abdul Moeloek berada pada range II yang berarti cukupsiap. Areakesiapan tertinggi padakomponen infrastruktur sehingga proses persiapan dititik beratkan pada pemberian sosialisasi, pelatihan dan penambangan sumberdaya pengembang teknologi informasi. Sedangkan secara kesel uruhan RSUD Kota Yogyakarta juga berada pada kategori cukup siap untuk mel akukan pengembangan rekam medis elektronik. Namun, hasil skor yang diperoleh mendekati batas bawah sehingga banyak areararea yang perlu dipersiapkan. Batas skor kesiapan untuk kategori cukup siap adal ah antara 50-97 sedangkan 
skor RSUD Kota Yogyakarta sebesar 51 hanya terpaut 1 angka dari batas bawah.

Infrastruktur yang perlu di persiapakan adalah terkait pengembangan SIMRS. Pengembangan SIMRS tersebut perlu di awali dengan pembuatan perencanaan yang dituangkan dal am dokumen rencana strategis. Proses tersebut hanus melibatkan berbagai profesi sehingga tepat kebutuhan. Dukungan sumberdaya manusiayang cukup familiar dengan komputer harus diikuti dengan pemberian sosialisasi terkait budaya kerja. Kemampuanyang handal tanpa adanyabudaya kerjayang baik makatidak akan mendukung adanya perubahan.Mencapai kesiapan secara teknis tidak cukupmendukung keberhasilan dal amimplementasi. Diperlukan kesiapan dimensi lain seperti kesiapan budaya, manajemen dan kepemimpinan, dukungan pemerintah dan kesiapan operasional juga harus diperhitungkan (Ghazisaeldi et al, 2013). Keempat dimensi kesiapan tersebut dapat diidentifikasi lebih lanjut sesuai keadaan lingkungan internal dan eksternal untuk dapat dirumuskan strategi dalam pengembangan berikutnya.

\section{Analisis Strategi Pengembangan Rekam Medis di Instalasi R awat J alan R SUD K ota Yogyakarta dengan M etode SWOT (Strength, Weakness, Opportunities, Treaths).}

Strategi merupakan perencanaan dan eksekusi sebuah aktivitas dal am kunun waktu tertentu.Terdapat tiga hal penting dalam suatu strategi yaitu; harus sesuai dengan situasi perusahaan; harus dapat membantu perusahaan mencapai keunggulan kompetitif yang berkesinambungan dan dapat meningkatkan performa organisasi (Saragih dan Harisno, 2014). Melihat pentingyastrategi tersebut, makadiperlukan adanya proses identifikasi kondisi lingkungan internal dan ekstemal organisasi di RSUD Kota Yogyakarta.

Salah satu analisis strategi yang juga digunakan oleh RSUD Kota Yogyakarta dal am pembuatan Rencana Bisnis Strategis (RBS) maupun Rencana Bisnis Anggaran (RBA) adalah dengan analisis SWOT. Analissi SWOT lebih mudah diterapkan dan di pahami jajaran manajemen sebagai pengambil keputusan. Analisis SWOT merupakan identifikasi berbagai faktor strategi internal (kekuatan dan kelemahan) dan eksternal (peluang dan ancaman) (Saragih dan Harsino, 2014).

RSUD KotaYogyakartayangsudah memiliki SIMRS menjadi salah satu kekuatan yang mendukung pengembangan rekam medis elektronik. Prasetya (2009) dalam penelitiannya juga menyebutkan bahwa adanya SIMRS telah membantu proses pelayanan pasien baik proses bi lling dan pendaftaran pasien. SIMRS yang ada saat ini sudah berfungsi sebagai billing, pendaftaran (rekam medis) dan pengel olaan beberapa Iaporan. Selain itu proses entry data diagnosis dan tindakan rawat jalan juga sudah mulai dilakukan. Hal ini menjadi cikal bakal pengembangan rekam medis elektronik.Sistem informasi memiliki peranyang sangatpenting dal am strategi bisnis organisasi. O'Brien dan Marakas (2011) menyebutkan bahwa sistem infromasi memiliki tiga peran penting dalam organisasi yaitu mendukung proses dan operasi bisnis, mendukung pembuatan keputusan oleh pegawai dan manajer, mendukung strategi-strategi keunggulan kompetitif. Dengan kata lain adanya SIMRS di RSUD Kota Yogyakarta dapat mendukung adnaya keunggulan kompetitif karena SIMRS dapat memberikan dukungan pengambilan keputusan dari pihak staf maupun jajaran manajemen. Selain itu pelayanan kepada pasien dapat didukung dengan adanya SIMRS.

Dukungan dari jajaran manajemen menjadi kekuatan bagi RSUD Kota Yogyakarta untuk dapat mengembangkan rekammedis elektronik. Dukungan tersebut langsung dipaparkan oleh pimpinan rumah sakit serta tertuang dalam Visi dan Misi rumah sakit. Misi merupakan pernyataan tentang apa yang harus dikerjakan oleh lembaga dalam usahanyamewujudkan visi. Dalam operasional nya orang berpedoman pada pernyataan misi merupakan hasil kompromi intepretasi visi. Misi merupakan sesuatu yang nyata untuk dituju serta dapat pula memberikan petunjuk garis besar cara pencapaian visi (Saragih dan Harisno, 2014) Dengan adanya visi dan misi yang mendukung pengembangan RME makan dukungan untuk penagembangan selanjutnya akan lebih mudah dilaksanakan. Altuwaijri (2011) dalam penel itiannya menyebutkan bahwa beberapa aspek penting dalam menunjang pengembangan RME antara lain visi IT, IT, proyek risiko, peran departemen IT, infrastruktur TI, dan manajemen proyek, pelatihan yang memadai, integrasi sistem, analisis kesehatan , situasi politik, dan analisis dampak.

Salah satu kelemahan yang dimiliki rumah sakit pemerintah adalah terkait infrastruktur.Hal ini juga dialami RSUP Dr. Soeradji Tirtonegoro Klaten (Kartika, 2014).Namun demikian infrastruktur di 
RSUD Kota Yogyakarta dipandang oleh jajaran manajemen sebagai sebuah kekuatan.Terkait dengan ketersediaan infrastruktur, RSUD Kota Yogyakarta sudah memiliki beberapa fasilitas pendukung untuk pengembangan RME ke depan seperti server dan komputer serta pengembangan resep online. Meskipun masih dalam kategoti cukup namun menurut jajaran manajemen infrastruktur menjadi kekuatan dalam pengembangan RME di RSUD Kota Yogyakarta.Direktur juga telah memberikan kesediaannya untuk mempersiapkan infrastruktur apabila regulasi tentang RME sudah jelas.

Aspek finansial menjadi persoalan penting karena rumahsakitharus menyiapkan infrastruktur teknologi informasi (komputer, jaringan kabel maupun nir kabel, listrik, sistem pengamanan, konsultan, dan pelati han) (Handi wijojo, 2009).Meskipun anggaran cenderung sulit untuk beberapa rumah sakit negeri namun RSUD Kota Yogyakarta telah berkomitmen dalam mendukung pengembangan teknologi informasi sehingga penganggaran lebih mudah didapatkan.Visi dan Misi rumah sakit yang mendukung pengembangan TI memberikan dampak pada kemudahan dal amanggaran pengadaan terkait pengembangan TI.

Beberapa kelemahan yang dimiliki RSUD Kota Yogyakarta terkait pengembangan RME antara lain terkait jajaran manajemen belum serius dalam pengembangan RME. RME tidak menjadi prioritas karena rumah sakit lebih mengutamakan sistemlain seperti sistem penagihan elektronik (computerized billing system), sistemakuntansi, sistempenggajian. Rumah sakit beranggapan bahwa semua sistem itu lebi h di utamakan karenadapatmenjamin manajemen keuangan rumah sakit yang cepat, transaparan dan bertanggung jawab.RME dinomor duakan karena sistempengel olaan transasksi untuk fungsi pelayanan medis masi h dapat dilakukan secara manual (Handiwidjojo, 2009). Hal tersebut juga terjadi di RSUD Kota Yogyakarta dimana pengembangan pertama kali untuk SIMRS adalah untuk proses billing. Jajaran manajemen masi $h$ bel umserius dalam pengembangan RME.Padahal saatini pengembangan pembiayan pelayanan mengarah pada diagnosis ataupun tindakan yang telah dilakukan.

Sumber daya manusia di RSUD Kota Yogyakarta sebagian besar bisa mengoperasikan komputer. Namun demikian optimalisasi dalam menggunaan SIMRS masih dinilai kurang. Proses input data dan kemauan untuk menggunakan SIMRS Iebih jauh dinilai kurang. Hal ini menjadi kelemahan dalam pengembangan RME di RSUD Kota Yogyakarta. Kekawatiran petugas dalam meberikan pelayanan menjadi al asantidak efektifnya pemanfaatan SIMRS. Staf cenderung takut akan bertambahnya beban pekerjaan. Peningkatan ratedari adopsi RME secara penuh dipengaruhi ol eh aspek prilaku penggunaan atau penerimaan pengguna (Rosyada, 2015).Dapat di katakan bahwa kemampuan sumber daya manusia harus di ikuti aspek prilaku terhadap penerimaan sistem. Tanpa adanya aspek prilaku yang berdedi kasi dalam perubahan maka aspek sumber daya manusia hanya menjadi kelemahan dalam pengembangan RME.

Pengolaan SIMRS berada di bawah Instalasi TI.Apabila terjadi permasalahan terkait SIMRS, proses perbaikan SI MRS dapat dilakukan oleh staf Instal asi TI.Namun demikian, apabilamasalahtidak teratasi makan dilakukan konsultasi kepada vendor. Proses konsultasi ini selal u mendapatkan respon, namun karena pi hak vendor tidak berdekatan dengan rumah sakit, maka prosesnyaperbaikan menjadi lebih lama. Kondisi tersebut menjadi salah satu kendala dal am proses pengembangan SIMRS.

RSUD Kota Yogyakarta memiliki staf TI sebanyak 6 orang. Menurut wawacara, jumlah staf tersebut masi $\mathrm{h}$ kurang apal agi adanya pengembangan gedung baru.Pengembangan $\mathrm{SI} / \mathrm{TI}$ dengan infrastruktur yang sudah baik harus diikuti dengan penambahan SDM untuk pengelolaan SIM, peningkatan pengatahuan user melalui pelatihan, menyusun bidang khusus menangani $\mathrm{SI} / \mathrm{TI}$, SOP SI/TI, Renstra SI/TI (I mayani, 2015). Untuk itu saat ini ketersediaan sumber daya manusia TI masih di pandang sebagai sebuah kelemahan di RSUD Kota Yogyakarta. Penambahan masih diperlukan untuk mendukung pengembangan RME ke depan.

Gondodiyoto (2007) mengukur kinerja sistem informasi membagi kinerja sistem infromasi berdasarkan dua bagian yaitu kepuasan pemakain dan pemakian sistem infromasi sebagai variabel kinerja sistem infromasi.Meskipun SIMRS sudah memberikan manfaat yang sangat banyak di RSUD Kota Yogyakarta. Namun demikian untuk bisa mendukung proses pengembangan ke depan masih memerlukan adanya penyempurnaan. Beberapa pengguna mengel uhkan kaitannya dengan sistem yang terkadang lambat pada jamjam pel ayanan.

Pemberian Sosialiasi dan Pelatihan Terkait TI yang masih kurang meniadi kelemahan dari sisi internal di RSUD KotaYogyakarta.Pelati han terkait dengan 
teknologi khususnya penggunaan SIMRS pernah dilakukan di RSUD Kota Yogyakarta yaitu pada waktu awal penerapan billing sistem. Namun demikian proses pelatihan yang berkesi nambungan belum dilaksanakan. Erawantini et all (2012) mengungkapkan bahwapelatihan penggunaan sistem pada users (pengguna) sangat penting sehingga mereka mampu menggunakan saat memberikan pelayanan kepada pasien. Namun demikian hal tersebut belum dilakukan secara periodik padahal banyak terdapat staf klinis yang baru.Selain itu pemahamantentang teknologi informasi jugamasih kurang.

Peluang yang dimiliki RSUD Kota Yogyakarta antara lain terkait adanya pengembangan Resume Online oleh Kementerian Kesehatan. Kementrian Kesehatan RI mengembangkan proses rujukan online untuk diterapkan di beberapa rumah sakit di Indonesia. RSUD Kota Yogyakarta menjadi salah satu rumah sakit uji coba untuk pengembangan rujukan online ini. A pabila proses bisa berjalan dengan lancar maka proses rujukan diikuti dengan pengiriman resume secara online Dengan adanya pengembangan resume online ini, maka RSUD Kota yogyakarta mendapatkan peluang untuk juga dapat mengembangkan RME sejalan dengan pengembangan resume online.

Ancaman yang dihadapi RSUD Kota Yogyakarta antara lain adalah pengembangan RME oleh Rumah Sakit lain semakin pesat. Beberapa rumah sakit lain di Kota Yogyakarta telah mengembangkan rekam medis elektronik. Hasil penelitian di kuwait memperlihatkan bahwa $96,5 \%$ pasien secara umum merasa puas dengan pel ayanan yang dberikan setelah penerapan rekammediselektronik (Al-Azmi, 2006). Hal tersebut memperlihatkan bahwa penerapan RME juga mendukung kepuasan pasien. Hal ini juga diupayakan oleh rumah sakit lain di Yogyakarta. Penelitian Markus (2010) juga menyebutkan bahwa penerapan rekammedis el ektronik rawatjal an di RS Panti Rapih Yogyakarta memberikan peningkatan pada mutu pelayanan.Melihat hal tersebut maka pengembangan RME dibeberapa rumah sakit di Yogyakarta menjadi ancaman bagi RSUD Kota Yogyakartaapabilatidak diikuti dengan perencanaan dan pengembangan lebi $\mathrm{h}$ lanjut.

Ancaman lain yaitu adanya perubahan Persepsi PasienTerhadap Pelayanan Rumah Sakit. Penelitian Al-Azmi (2009) mengungkapan bahwasecaraumum penerapan RME memberikan kepuasan bagi pasien. Namun Meski pun secara umum penelitianAl-Azmi
(2006) memperlihatkan adanya kepuasan dari pelayanan secara umum, namun terdapat beberapa item kepuasan yang bernilai rendah yaitu sebesar $46,5 \%$. Item dengan kepuasan rendah ini terkait dengan penjelesan mengenai prosedur oleh dokter. Hal ini menjadi salah satu acaman pula bagi RSUD Kota Yogyakarta yang memiliki pasien kalangan menengah ke bawah.

Dukungan undang-undang menjadi salah satu ancaman dalampengembangan RME. Hasil penelitian Yusuf (2013) menunjukkan bahwa wal aupun RME memiliki dasar hukum yang kuat dengan adanya Permenkes No.269 Tahun 2008 dan undang undang Infromasi dan Transaksi Elektronik. Namun undang undang secara khusus yang mengatur RME belum ada sehingga membingungkan pelaksana.

Persaingan antar rumah sakit juga menjadi ancaman bagi pengembangan RME di RSUD Kota Yogyakarta. Rumah sakit di Yogyakarta dengan persaingannya yang ketat berusaha memberikan pelayanan terbaik bagi pasiennya.J umlah rumah sakit tersebar hampir diseluruh Kota Yogyakarta. Lokasi RSUD Kota Yogyakarta yang berada disisi selatan Kota Yogyakarta memiliki dampak persaingan yang sangat ketat.Rumah sakit swasta di Kota Yogyakarta cenderung memiliki reputasi baik di kalangan konsumen. Dan saat ini, beberapa rumah sakit swasta besar telah mengedepankan RME untuk pelayanannya khususnya pelayanan rawat jalan. Hal ini merupakan nilai tambah bagi rumah sakit tersebut sekaligus menjadi ancaman bagi RSUD Kota Yogyzkarta. Dalam Industry and Competitiveanalysis(ICA), Porter mengungkapkan bahwa keadaan kompetitif bergantung pada lima kekuatan kompetitif yaitu: daya tawar pemasok, daya tawar pembeli, ancaman pendatang baru, ancaman pengganti, serta persai ngan sesama (Ward, 2002). Dalam hal ini, rumah sakit lain di sekitaran Yogyakarta merupakan memegang peran sebagai pesaing yang berpengaruh padakekuatan kompetitif RSUD KotaYogyakartauntuk terus mengembangkan pelayanannya.

Kondisi internal dan eksternal yang telah disebutkan, diukur dengan memberikan skor untuk masingmasing aspek. Hasil rekapitulasi kuesioner di peroleh hasil penilaian untuk masing-masing kondisi lingkungan internal dan eksternal.Selain itu juga dilakukan identifikasi EFAS (Eksternal Factor Analysis Summary) dan IFAS (Internal Factor Analysis Summary) untuk ragam strategi yang ditawarkan. 
Hasil dari perhitungan diperoleh skor untuk kekuatan adalah sebesar 3,05; skor untuk kelemahan sebesar 2,96; skor untuk peluang sebesar 3,82 dan untuk ancaman sebesar 3,98. Hasil perhitungan skor tersebut menunjukkan bahwa titik temu antara $x$ dan y berada pada angka $(x=0.09, y=-0.17)$ yaitu pada kuadran II.Berikut hasil gambaran kondisi lingkungan RSUD Kota Yogyakarta dalam pengembangan RME dalam diagramkartesius:

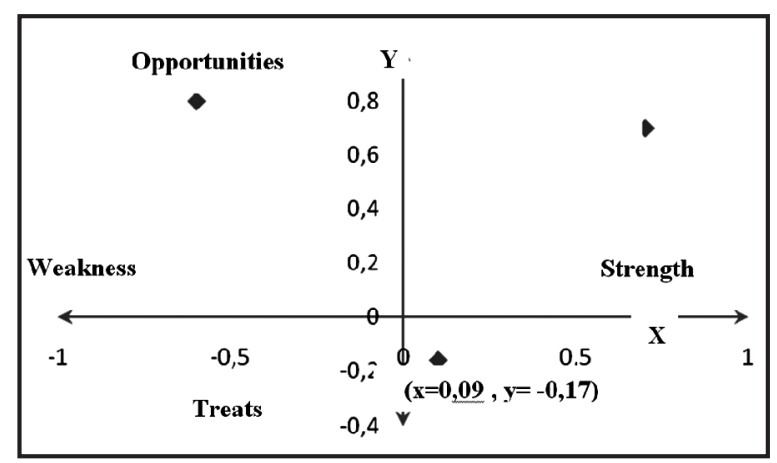

Posisi di kuadran II menunjukkan sebuah organisasi yang kuat namun menghadapi ancaman yang besar. Rekemonedasi strategi yang di berikan adalah diversifikasi strategi artinya perusahaan dalam kondisi mantap namun menghadapi sejumlah tantangan berat sehingga di perkirakan roda perusahaan akan mengal ami kesul itan untuk terus berputar bi la hanya bertumpu padastrategi sebel umnya. Oleh karenaitu organisasi disarankan segera memperbanyak ragam strategi yang taktis (Saragih dan Harisno, 2014). Startegi yang disusun adalah dengan menggunakan kekuatan untuk memanfaatkan peluang jangka panjang (Ayuni ngtyas, 2013). Hasil anal isis strategi menunjukkan bahwastrategi yang ditawarkan adal ah dengan diversifikasi strategi.Hasil identifikasi EFAS dan IFAS menghasilkan banyak strategi yang dapat dilakukan, namun strategi yang lebih ditawarkan adalah dengan memanfaatkan kekuatan untuk menghadapi ancaman.

\section{Tabel 5. Matriks EFAS (Ekstemal Factor Analysis Summary) dan IFAS (Internal Factor Analysis Summery)}

\begin{tabular}{|c|c|c|}
\hline IFAS & Kekuatan & Kelurangan \\
\hline EFAS & $\begin{array}{l}\text { 1. Dukungan SIMRS dalam } \\
\text { pengembangan RMIE } \\
\text { 2. Dukungan Manajemen } \\
\text { 3. Dukungan dokter } \\
\text { 4. Dukungan Infrastruktur } \\
\text { 5. Dukungan Anggaran }\end{array}$ & $\begin{array}{l}\text { 1. Manajemen kurang serius dalam } \\
\text { pengembangan } \\
\text { 2. Kemampuan dan kemauan staf medis } \\
\text { 3. Kinerja perbaikan dalam pengembangan } \\
\text { 4IMR } \\
\text { 4. Ketersediaan SDM Programing } \\
\text { 5. Kinerja SIMRS Kurang Optimal } \\
\text { 6. Sosialisasi dan Pelatihan kurang }\end{array}$ \\
\hline $\begin{array}{l}\text { Kesempatan } \\
\text { 1. Pengembangan } \\
\text { resume online } \\
\text { 2. Pengembangan } \\
\text { RSUD menjadi } \\
\text { rujukan regional } \\
\text { 3. Peningkatan peran } \\
\text { teknologi Informasi }\end{array}$ & $\begin{array}{l}\text { 1. Pembuatan modul program resume } \\
\text { online yang sejalan dengan } \\
\text { pengembangan RME } \\
\text { 2. Pengembangan sistem rujukan yang } \\
\text { lebih efektif efisien didukung dengan } \\
\text { RME } \\
\text { 3. Pemanfaatan teknologi informasi } \\
\text { didukung dengan sistem infrastruktur } \\
\text { TI yang sudah ada } \\
\text { 4. Perencanaan Anggaran untuk } \\
\text { pengembangan RME }\end{array}$ & $\begin{array}{l}\text { 1. Proses penguatan staf untuk } \\
\text { pengembangan SIMRS dengan teknologi } \\
\text { infromasi yang mengikuti perkembangan } \\
\text { TI } \\
\text { 2. Penambahan staf TI terkait } \\
\text { pengembangan SIMRS } \\
\text { 3. Melakukan analisis terhadap SIMRS } \\
\text { terkait perencanaan pengembangan ke } \\
\text { depan } \\
\text { 4. Memberikan pelatihan terkait teknologi } \\
\text { informasi dan sosialisasi pemanfaatan TI } \\
\text { yang semakin pesat }\end{array}$ \\
\hline $\begin{array}{l}\text { 1. Rumah sakit lain } \\
\text { telah beralih ke } \\
\text { RuE } \\
\text { 2. Perubahan persepsi } \\
\text { pasien dalam } \\
\text { pelayanan } \\
\text { 3. Dukungan undang- } \\
\text { 4. Persaingan antar } \\
\text { rumah sakit dalam } \\
\text { pelayanan kesehatan }\end{array}$ & $\begin{array}{l}\text { 1. Penyusunan rencana strategis SI/TI } \\
\text { 2. Mulai mengembangkan Modul RME } \\
\text { 3. Dipilih dokter dengan kemampuan } \\
\text { projed pemanfaatan teknologi } \\
\text { informasi } \\
\text { Menyususun kebijakan terkait } \\
\text { undang-undang yang sudah ada } \\
\text { Sosialisasi penerimaan } R M \text { IE untuk } \\
\text { pengguna maupun pasien }\end{array}$ & $\begin{array}{l}\text { 1. Menyusun rencana pengembangan RME } \\
\text { 2. Pemberian reward untuk staf berdedikasi } \\
\text { tinggi dalam memberikan pelayanan } \\
\text { 3. Optimalisasi alur pelayanan dengan RME } \\
\text { untuk memberikan pelayanan yang } \\
\text { efektif dan efisien }\end{array}$ \\
\hline
\end{tabular}

- - - : rekomendasi strategi 
Strategi penting yang harus segera di lakukan adal ah terkait penyusunan perencanaan sistem informasi di RSUD Kota Yogyakarta.Perencanaan sistem informasi merupakan bagian yang penting sebagai petunjuk pengembangan dal am kurun waktu 3 atau 5 tahunan. Proses perencanaan memperhatikan misi, sasaran dan strategi, proses bisnis dan informasi yang di butuhkan di organisasi dan kemudian dipakai untuk identifikasi untuk memilih sistem yang perlu dibangun dan disediakan beserta penjadwal an dan kebijakan-kebijakan yang diperlukan. Hasil dari perencanaan tersebut benupa rencanastrategi sistem informasi dan teknologi infromasi ( Kadir, 2014). Rencana Strategis yang disusun harus bersama sama mengikutsertakan profesi-profesi di RSUD KotaYogyakarta. Fungsi lintas profesi adalah untuk mengetahui kebutuhan-kebutuhan tiap profesi yang terkait dal am pengembangan RME. Dalam hal ini RSUD KotaYogyakarta harus segera menyusuntim eksekutif perencanaansisteminfromasi rumah sakit.

Berdasarkan penilaian dengan elemen penilaian dari DOQ-IT, RSUD Kota Yogyakarta cukup siap untuk mengembangkan RME. Untuk itu penyusunan modul untuk RME dapatsegera di realisasikan. Untuk efektivitas dalam proses perencanaan akan lebih baik bila proses tersebut dapat berjalan bersamaan dengan proses resep online. Alternatif strategi yang lain adalah dengan melaksanakan terlebih dahulu penerapan resep online dengan sistem pilot project. A pabila proses berjal an lancar maka proses pendokumetasian rekam medis secara elektronik dapat dilakukan setelahnya. Untuk mendukung hal tersebut maka perencanaan dan penganggaran untuk penyusunan modul rekam medis elektronik dapat dimasukkan dalam rencana anggaran tahun 2017. Seluruh proses pengembangan resep online dan perencanaan pengembangan RME tersebut harus diawali dengan sosial isasi terlebi h dahulu. Sosial isasi ini juga dimaksudkan untuk memberikan motivasi serta persepsi positif dal ampengembangan teknol ogi infromasi untuk pelayanan yang lebih efisien.

\section{SIMPULAN}

RSUD KotaY Yogyakartamasuk dal amkategori cukup siap untuk pengembangan rekam medis elektronik berdasarkan EHR and Readiness Assessment oleh Doctor's Office Quality Information Technology
(DOQ-IT), (2009). Hasil skor masih berada pada batas bawah kategori cukup siap sehingga masih banyak aspek yang harus di penuhi sesuai komponen dalam penilaian. Empat parameter penilaian yaitu sumberdaya manusia, budaya kerja, tata kelola kepemimpinan dan infrastruktur dalam kategori cukup siap. Nilai tertinggi berada pada parameter sumberdaya manusia.

\section{DAFTAR PUSTAKA}

Al Azmi, SF, Mohammaed AM, Hanafu MI. 2006. PatientSatisfaction with Primary Heal th Care in Kuwait after Electronic Medical Record Implementation.J urnal. Diaksesdari http:// www.ncbi.nlm.nih.gov/pubmed/18706302. pdf pada 10 A pril 2016 pukul 19.00 wib

Bungin, B. 2010. PenelitianKualitatif. Jakarta :KencanaPrenada Media Grup

Hasan, R., Kristen V., Michele C. 2014. Progress And Challenges in The Implementation of Electronic Medical Records in Saudi Arabia: A Sistematic Review. Health infromatic An International J ournal. Diunduh dari http:// airccse.org/journal/hiij/papers/3214hiij01.pdf

Hatta, G. 2008. Pedoman Manajemen I nformasi Kesehatan di sarana Pelayanan Kesehatan. J akarta :BP UI

J immy L. Gaol. 2008).Sistemlnformasi Manajemen, Pemahanan dan A plikasi . Jakarta: Grasindo

Kadir, Abdul. 2014. Pengenalan Sistem Informasi Edisi Revisi.Yogyakarta: PenerbitAndi

Katterhagen, Lori. 2013. Implementation Plan for EMR and Beyond. Doctor of Nursing Practise (DNP) Project Paper.Diaksesdari http://repository.usfca.edu/cgi/viewcontent. cgi? article $=1031 \&$ context $=$ dnp.pdf pada 10 Mei 2016 Pukul 14.00 wib

Koolaee, M H., Atharaslsadat Mirkarimi., Nase Behnampoor., Mohammad J avad Kabir. Readiness Assessment of Laboratory and I maging Staff to I mplement Electronic Health Records.I Iranian J ournal of Medical Infromatics. Diakses dari http://ijmi.ir/journal/ index.php/lJ MI/article/downl oad/70/98.pdf pada 10 Mei 2016 pukul 20.00wib 
Muhammad Hamdani Pratama dan Sri Darnoto. Anal isis Strategi Pengembangan Rekam Medis ...

Miller, Robert H; Sim, Ida. 2004. Physician's Use Of Electronic Medical Records: Barriers And Solutions. Diaksesdari http://content. heal thaffairs.org/content/23/2/116.full.pdf pada 19 Maret 2016 pukul 20.00 wib

Oetomo, B.S.D. 2002. Perencanaandan Pembangunan Sistem Informasi, Yogyakarta: Andi Offset

Permenkes 269/PER/III/Tahun 2008 TentangRekamMedis

Pereira, Rui., Maria Salazar., Antonio Abelha dan J ose Machado. 2011. SWOT Analysis of PortugueseElectronic Heal th Record. J urnal. Diakses dari http://dl.ifip.org/db/conf/i3el i3e2013/PereiraSAM 13.pdf
Prasetya, Albertus Widyawan Heri. 2009. Evaluasi Implementasi Sistem Informasi Manajemen Rumah Sakitdi RSUD KotaYogyakarta. Tesis (tidak dipublikasikan). Yogyakarta: Program Pasca Sarjana Universitas Gadjah Mada.

Potter, P. A., \& Perry, A. G. (2009).Fundamental of Nursing. Sydney: Amy Hall

Rahayu, I S. 2015. Kesiapan Penerapan RekamM edis Elektronik di Instalasi Rawat Jalan RSUD Dr.H.Abdul Moeloek Provinsi Lampung. Tesis (Tidak dipublikasikan). Yogyakarta: Program Pasca Sarjana Universitas Gadjah Mada.

Sabarguna, B.S danFarlan S. 2008. Rekam Medis Terkomputerisasi. J akarta: UI Press. 